\title{
Pituitary Gland Basophil Adenoma
}

National Cancer Institute

\section{Source}

National Cancer Institute. Pituitary Gland Basophil Adenoma. NCI Thesaurus. Code C2856.

An epithelial neoplasm of the anterior pituitary gland in which the neoplastic cells stain positive with basic dyes. 